\section{SOI: 1.1/TAS DOI: 10.15863/TAS International Scientific Journal Theoretical \& Applied Science}

p-ISSN: $2308-4944$ (print)

e-ISSN: 2409-0085 (online)

Year: 2016

Issue: 2

Volume: 34

Published: 29.02.2016 http://T-Science.org
Gary B. Lapiz

B.A. in Political Science, Ed. Units, DSPED, B.P.A., M.A.Ed., M.P.A., D.P.A. Resident Faculty, College of Arts and Sciences, Cebu Normal University, Cebu City, Philippines instructor_lapiz@yahoo.com.ph

SECTION 19. Management. Marketing. Public administration.

\title{
THE POLITICS OF ZETA'S LIFE STORY
}

Abstract: This paper presents on narrative Zeta's (pseudonym) life story, an undefeated political leader in Cebu who survived politics despite its challenges. Despite old age at 74, she has prolonged her career which in this paper, the researcher has eventually stated her experiences through interviews on transcription relative to her sustenance in her position along with her eventual responses. Using the descriptive-qualitative-narrative presentation in a nutshell, the researcher ends on conclusion how Philippines, has equally treated women with respect and dignity at par which transcends gender among all civilizations.

Key words: Descriptive-qualitative-narrative presentation, Undefeated political leader, Zeta's life story.

Language: English

Citation: Lapiz GB (2016) THE POLITICS OF ZETA'S LIFE STORY. ISJ Theoretical \& Applied Science, 02 (34): 36-41.

Soi: http://s-o-i.org/1.1/TAS-02-34-6 Doi: crossef http://dx.doi.org/10.15863/TAS.2016.02.34.6

\section{INTRODUCTION}

Preliminary report (as of September 2013) of the May 2013 automated national and local elections shows that around 19.97 percent $(3,503)$ of the elected posts, including ARMM elections, are won by women candidates, higher than the 18.4 percent turnout in 2010. The number of women who filed candidacy for the election period was only 7,925 or 17.83 percent of the total number of candidates [1].

The preceding citation from the Philippine Women Commission manifests clearly that the rise of women in governance and politics in the Philippines has been inevitably undeniable. Though developments for women in politics and decision making are promising, growth has been slow and the proportion of women and men in this area is still far from equal. The country may have had two women leaders, former Presidents Corazon C. Aquino and Gloria Macapagal-Arroyo who came into power through the EDSA I and EDSA II people's revolt, however, men's domination in the political arena remains apparent. The 2007 data from the Commission on Elections reveal a total of 2,881 women in national, provincial and municipal elected positions which translate to only 17 percent share of the total turnout, 83 percent of those elected were men [2].
With the rise of women in the national arena including success stories of those who are in power, there are some of those female local leaders that are unaccounted on narratives. Much have been written about national politics in the Philippines brought about by a centralized system of governance with less consideration to the local settings, a reminder that as a country, it is comprised of approximately 7, 107 large and small islands (Luzon, Visayas and Mindanao). Politics in public administration is not only concentrated in the national government but also to its component parts (the local government units) which contribute to the entirety of the country's political development. This is to say that Philippine politics is so rich in theory and practice that it cannot be isolated to the national government only but "is supposed" a mirror of all politics, a summation of everything about a country [3].

This paper is an attempt to pay attention on tribute that with the struggle of women for recognition in the picture, there are still those unsung female leaders in the local level who shall be treated on accounts since there are only few chroniclers that write on them (local female leaders) versus those who are women in the national panoramic scale of governance.

With the aforementioned reality, the author writes about a female leader, who despite odds has 
survived politics with all her means towards its Machiavellian end-to acquire, retain and expand power [4]. The Chronicle of Zeta (pseudonym) is a distinct life-story of a seventy-four (74) year old woman in Cebu. As per written on account, she has been labeled, "The .38 Woman due to one of the highlights of her story where she revealed that in order for her to save herself on political strategy, she used a ".38 caliber pistol on attempt against her male political opponent who challenged her integrity over her success in electoral results.

\section{OBJECTIVES OF THE STUDY}

This paper aims to present on "narrative" the political life-story of Zeta (pseudonym), a 74 year old woman in Cebu.

\section{MATERIALS AND METHODS}

This research is a descriptive-qualitativenarrative presentation of the life story of Zeta in Cebu. As per the conduct of the study, the researcher, as a political scientist, biased on the selection of a political subject meant for an interview vis-a-vis "chronicling" on value judgement as per choice on normative-prescription where the data had been processed towards its sound and valid conclusion along with its recommendation. As stated by Tuibeo, a political Scientist has no interest in the "whys" and "wherefores" of politics, but mainly in what is observable and quantifiable, let alone describable [5].

\section{RELATED STUDIES}

Lapa, P. (2004) wrote about leadership that "managers are expected to play the roles of being "politicians", "diplomats" and "symbols" who make difficult decisions." This may mean that leaders in discharging their duties take into practice political power [6].

Tampus, L. (2000) mentioned about the play of politics in leadership. He stressed that "the greater challenge is the myriad of the changes that confront us in the larger arena leadership and politics. Though there are a lot of training being conducted in every institution, there are still personal behaviors that dominated because of vested interests, lack of foresight and creativity. Some leadership behaviors are products of greed and grandstanding personality, which has imbibed the responsibilities because of nepotism, wealth, fortune and popularity [7]."

Rama, F. (2002) in her research conclusion states that the "Organizational Culture and Work Values of the selected local government units are found to be interrelated. This is because the management principles adopted by the managers were actually intertwined with our Filipino Cultural Values, which when mixed and matched determined behavior and attitude of the work values of both government officials and employees [8]."
Trani, A. (2007) concluded in his study emerging leadership styles of two local chief executives in Talisay City, Cebu. It turned out that Local Chief Executive A combined the autocratic and democratic styles while Local Chief Executive B was laissez-faire or free-rein. Both leadership styles are described by Kurt Lewin. The perception of the constituents indicated both of the chief executives' leadership styles [9].

Lubguban, M.G. (2010) mentioned, "Women leadership in the national capital region is not a rare case in the Philippines. Although in the past, women in Siquijor were confined in the home, they however took important roles like taking care of the children and assisting their husbands who worked for the family's income [10]."

Laplap, C. F. as cited by the Philippine Association for Graduate Education Journal indicates that "the number of female top managers has increased because more women have ventured into fields and occupations formerly dominated by men. (Cont. in the next paragraphs) The number of women who hold the most senior positions of leadership serving has risen since 1970. However, women managers are scarce as supported by Burke (2005) who mentioned that women merely comprise less than $0.005 \%$ of the world's political, business and industrial leaders [11].

\section{RESULTS AND DISCUSSION}

Zeta, 74 years old, female, widow, has an estimated annual income in year 2010 including allowance as 492,000 pesos and a monthly pension of 16,000 pesos. Although, she worked as an employee in one of the bureaus of the government, she served as an elected politician in her place for 12 years. When she started in politics in 1969, she ran as an independent candidate and won as a barangay councilor. Later, after she served one of the bureaus of the government, she ran again for city councilor which she won consecutively, holding office until the present times. She graduated along with her educational achievement in her college degree.

Zeta, who when interviewed took her medications, continuously citing enthusiastically her experiences in political practice. When asked about political leadership, she replied:

\section{Zeta's Experience on Deception}

"Daghan kaayo ang mga higayon nga ilaron ka. Ingnon nga tuay na hospital, unya to mangayo ug kwarta nga ibayad sa hospital nya himan-himan wa diay. Hay Ginoo! Unya to daghan kaayong ilad. Ilaron pa ka nga namatay ang iyang anak, wa diay. Mangayo ug dakong kantidad, hinabang. Mao ni ang mga negative sa pamolitika. Nya magsolicit daghan kaayo moingon nga nagkasakit, naay na hospital, naay nanganak, naay giataki. Hinoon dunay giataki 
mohapit diri manghuwam sakyanan, imo pang krudo, imo pang driver nya inig naa na ang driver ug krudo, moingon man ug unsa may i-down? Wa man mi kwarta. Taga-an na sad nimo 500 aron lang gyod makalakaw, nya ang driver imo, imo pang krudo. Pastang paita, mao nang kasinatian nga pait gyod. (There are many times that you are deceived. Saying that somebody is hospitalized, then asking money for the hospital payment then actually, it's not true. Oh God! There are so much lies. You are deceived that his son died, it's not true. Ask for bigger amount, donation. This are negative in politics. Then many solicit, ill, there's in the hospital, labor, attack. However, somebody drops by here to borrow vehicle because of attack, you shoulder the crude, the driver, then when there's the driver and the crude, somebody will say, what are we going to pay for the down payment? We don't have money. You give 500 so they can leave, plus the driver and the crude. So bitter, so much bitter experience.)

She further elaborated that once in her experience:

\section{Zeta's Act of Charity}

"Naay usa ka higayon nga namatay ang iyang bana, nya naghilak-hilak kay wa makuha sa ponirarya, aw wa makuha sa ospital, nihatag sad intawn ko ug 3,000 kay aron makuha ang patay, nya himan-himan wa man diay namatay (laughs). Nakitan man nako pagsunod tuig, buhi man lagi. Nikatawa na lang ko. Ingon ka, grabe gyod nimo mangilad oy, imo man giingon ana imong bana. Unsay tubag? Tungod sa among kalisod konsehal... Pwerte gyong ngilngigang mangilad, hay Ginoo ko! (There was one time that her husband died, she pretended crying because the body could not be claimed from the funeral, I mean could not be claimed from the hospital, I gave 3,000 so she could claim the dead, but actually there's nobody who died (laughs). I saw the following year, he's alive. I just laughed. You said, too much do you lie, you do that to your husband. What was the answer? It's because of our poverty councilor... So much expert in lying, oh my God!)"

Building good relations to one's fellowman is the key for one to stay in power citing that:

\section{Zeta's Values in Leadership}

"Nakapabilin gyod kanang relationship sa isigkatawo, (I sustain because of my relationship with others), pagpakabana, pagpaubos, paghigugma ug pagkamanggiloy-on (awareness, humility, love and merciful) pero mapurdoy lang ka pero ang tawo di gyod mubiya nimo tungod kay daghan man ka ug nahatag ug natabang mao nga ilhon to nila nga dakong utang boot. (however, you'll get poor but man will never leave you because you have given and helped, they will treat that as debt-of-gratitude.)"

This, she said, she has helped many people already including a child who was a kidney victim and has survived out of death.

"Nanghupong wa na naitsura ang nawong (the face bloated, unidentified)"

She also helped the release of an imprisoned woman who has three children $(3,5$, and 7$)$. So small are the children that she pitied so much, for according to her, all kids were all crying when she saw them visit their mother. She said:

"Gitabangan nako nga makagawas. Ang kaso nangawat ug baka. Nakagasto ug kwarta. Gipahearing, gi-motionan, gipangita sa Pit-os, kinatomoyan sa San Fernando. Nakagawas, pwerteng lipaya. Wa nangawat, naboang siya. Ang iyang bana dagmalan siya. Nagtoo ang babaye nagtoo nga iya ang baka paghuman gidala na sa prisohan. (I helped so she could be free. The case was about the stealing of the cow. I spent money. It was heard, it was motioned, searched in Pit-os, the farthest end in San Fernando. Was freed, was very happy. Did not steal, she was crazy. Her husband battered her. Because she thought it was her cow, after that she was brought to prison.)"

She estimated spending almost 30,000 pesos just to solve the case including the medication of the mother, the hospitalization and other miscellaneous fees. According to her, she has commitment to the Lord, the very reason of her service to the poor to the best that she could. She even added helping another constituent in her locality who had cancer in the brain adding that because it is her passion why that certain constituent continues to live until now.

"Sangko sa langit akong kalipay basta naay nasalbar nako nga himatyon nya nabuhi tungod nako. Hastang lipaya nako. (My happiness is up to heaven when I have saved the dying then has survived because of me. I am so happy.)"

However, there are really times when she is pressured and hesitant in helping especially when she does not have the money but for her, everything is a mystery because she believes God is at her back, guiding her in her mission to serve the poor and those who are in need. She prays intensely.

"God will provide gyod. Ngano makahatag man gyod ko? (God will really provide. Why can I still provide?)" saying:

With all her experiences, she summed up by

"Paet ang politika. (Bitter is politics.)"

As a politician, she narrated her long story over her experience about a certain opposition candidate who questioned her when she won as an independent candidate in 1969. She elucidated:

Zeta's Story about the .38 Caliber Pistol against a Political Opponent

"Kato independent ko diri kay gikontrahan ko ato, sa pabrika kay kuan ko ato-, man na diha nya ako (member of the opposition against the 
incumbent). Katong pagkuan, si-ba, katong kapitan nga pabor kay diha ba pwerteng hibonga nagubot sila, nganong nidaog man na!?! Independente pa nya number one pa!?! Ngano man siya, unsa bay iyang sikreto? Patawag ko niya, ingon akong nahibaw-an, mga (her family) — maldito. (When I was independent here, I was opposed, in the fabric because I was-, there because I was (member of the opposition against the incumbent). When it was, sithe captain that was in favor because they so wondered in chaos, why did she win!?! Just independent then turned out number one!?! Why her, what is her secret? He called me, accordingly I know, (her family) - notorious.) Unsa man ka, kamao ka ani? Ingon ko, unsa man diay ang imong pagpatawag nako Sir, imo day gisukod ang akong katakus, babaye man ko Sir, ayaw Sir oy, Coronel ka Sir nya imong kong hagiton ana, ayaw oy. Dako kaayo nga sayop ang imo mura noon ka ug naminos ana pagkabutanga. Kinsa man ko nga imong questionon, imohang pa demonstraton nga ikaw mismo nasayod nga babaye gud ko, wa gyod koy kasinatian? (What are you, do you know this? I said, what is that you call me Sir, you measure my prowess, I am a woman Sir, no Sir, you are a Coronel Sir then you are provoking me, no. That's a grave mistake from you, it's like you depreciate yourself in that manner. Who am I for you to ask me, you let me demonstrate, that you yourself know that I am a woman, I don't have the experience?) Ingon day siya, gidungog man ang mga- nga hawod ug maldito mao ni.. ana ana.. Dili ang tanan Sir, duna tinood pero di sad tanan Sir oy! Usa ko ana nga wa. Ang akong amahan buotan kaayo. (He replied, it is known that the - are known to be superior and notorious, this is it... then... It's not all Sir, there are those who are true but not all Sir! I am one that I am not. My father was very virtuous. Ingon siya, nakapusil na man kono ka!?! Ngano man nga imo man kong inteviewhon nga isog-isog? Unsa man diay $n i$, di man ni korte Sir? Ingon siya, ay soberbiya! Di man ni korte, nga di man ni korte, imo man kong balitok-balitokon. Ingon dayon siya, nabaniog man gud, nabaniog ba, nya nahibong man ko nga independente nya nakadaog ka. Pagboot man na sa tawo Sir di man na ako. Una sa tanan sa Ginoo, ikaduha sa tawo. Ang Ginoo ug naghatag nila, gilamdagan ang hunahuna sa tawo nga moboto nako, nya sala ba day na nako Sir? (He said, you were able to shot someone!?! Why do you interview me with arrogance? What is this about; this is not the court Sir? He replied, oh subversive! This is not the court, which this is not the court, you maneuver me. Then he said, it is known, that is known, then I wonder that you are independent yet you win. That is the will of the people, not mine. First of all, to God, second, it's about man. God is the one guiding them, blessing their minds that they will vote for me, is that my fault Sir?) Ngano masuko man ka nga makadaog ko? Ingon siya, wa ko masuko, nahibung lang ko nga mao ni ana. Ingon day siya, nakapusil man gyod ka, unsa ang armasa imong gipusil? Ingon ko, 38 man to Sir kay ang 45 mukak pa man. (Why are you mad when I win? He said, I am not mad, I am just wondering this and that. Then he said, you shot somebody, what gun did you use) I said, it was $38 \mathrm{Sir}$ because 45 still triggers.) Ingon, dayon siya, kini kamao ka ani? Ingon ko, kon ako nang kakon Sir, moboto man na. Kupta dayon! Yawa ra! Ingon ko, once na nga akong kakon Sir, ako gyod nang ipusil kay basin ug unhan ko nimo. (I said, once I'll trigger that Sir, I'll shot it because you might do it first.) Ingon siya, ah, ngiga ah, babaye pa! Ingon ko, unsa man imo man nang armas, unya imong ipakak nako, simbako ug naay imo diha nya imo dayon diha kong planteran nga gikuan tika. Kakuyaw nimo Sir, di ko mokak ana Sir, kay imo man na. (He replied, oh, a woman! I said, that is your gun, then you'll let me trigger it, you might have planted your own that I will use it against you. You are dreadful Sir, I won't trigger that Sir, because that is yours.) Gada man ko diri. Kini hinoon Sir uh! Akong gitionan. Kini Sir wa ni kakak pero oras nga imo kong lisodlisoron ipaboto ko ni, (I am bring my own here. This one Sir, uh! I pointed him the gun. This one Sir, this doesn't trigger but by the time you will make things difficult for me, I'll shot you, pastang tawag sa gwardiya lagi da! Lagot man ko. Ipakak niya basin simbako iplanted to. Kuyawa nimo Sir ah! Kanang Calvin, kamao ka? Ayaw nalang ko pangutan-a Sir. Ngano kana mang butanga imo pangutana nako, di gud ko laki, babaye ko sir oy. (So much that he called the guard! I was pissed. He let me trigger, possible that it was planted. You are dreadful Sir ah! About Calvin, do you know? Just don't ask me Sir. Why do you ask me about those things, I am not a man, I am a woman Sir.) Sos kalisod ana imong pangutana. (How difficult your question is) Nasina, nasuko man to siya nganong nidaog ko. (Envious, he was mad at me why I won.) Ako ra may tawo ni- ato nga nidaog. Bastang hanggawa atong Captain-. Abi nimo pagkasunod semana niari nako ang boang, ingon, Gingging, patay, maayo ning barkada ta ani da! Ingon, ko, barkada? Nganong barkada man ta? Ingon siya, ngiga nimo oy, kamao man day ka sa tanang armas mogamit. Ingon ko, dili Sir oy, 38 ra Sir kay mao ra may nakapatay. Makigbarkada noon, sos diyot-diyot naay meeting sa Apo Cement, ay wa na, gipatawag ko. Ingon ko, kayabag aning tawhana, unsa may nasulod sa ulo ani oy. Mao si Titi Fredo (her brother), magsunod-sunod na ug asa ko, makuwayan kay ug simbako maunsa ko." (I was the only person of - who won. How truly stupid was Captain-. You know the following week, he went over, saying, Gingging, to death, it's so good that we become friends! I replied, friends? Why are we friends? He said, you are an expert, you know about using guns. I said, Sir, it's not, only $38 \mathrm{Sir}$, because it 
killed. He befriended, suddenly there was a meeting in Apo Cement, I was being called. I said, how foolish this man is, what's in his mind. That is why Titi Fredo (her brother), follow me wherever I go, was afraid something might happen to me.)

Her motivation as she mentioned are the poor, she intentionally said:

\section{Zeta's Motivation in Leadership}

"Kana gyong mga kabus, kanang mga dato di na mobaws bisan unsaon pa na nimo ug tabang. Baliwa ra na nila ang tabang. Pero ang kabus, iampo pa ka. Dili tanan pero kargado gyod, iampo pa ka. Diha ko makabaton ug gugma sa mga kabus. Malipayon man kaayo ko bisan napurdoy ko. Ang misyon nako, kanang mga priso gitudloan nako ug rosaryo, bisan ang mga taga- (Those who are poor, those rich do not repay whatever you do to help them. They don't value deed. But the poor, they will pray for you. Not all, but mostly, they will pray for you. My mission is to teach prisoners the rosary, even those who are-..)"

She continued that for one to stay in power, it is important to advocate on the importance of moral values.

\section{Zeta's Reason for Her to Stay in Power}

"Ang imong moral values. Ang imong pagkatawo, nga dili ka manglaki, nga mga buhat nga dili maayo, mga babag nga tinguha nga gusto silang modaog. Pero ang imong pagkatawo limpyo, way mantsa. Wa gyod ka maghatag ug buling sa mata sa imong mga kaubanan, sa katawhan, sigurado gyod na ang mga tawo mopaluyo. (Your moral values. Your personality, that you don't cohabit with another man, wrong actions, those are hindrances of their desires to win. But if your personality is cleaned, not stained. You don't show dirt in the eyes of your collegues, the people, men will surely be behind you.)"

She added that the very reason why she is still in position are the people who need her help, most of all her family and relatives stressing that is easier to help if you hold a position in the government.

"Ang akong mga pinugsan. Ang mga tawo nga nakatabang ko sa ilang panginabuhi, sa ilang panglawas. Dili nako matalikdan labi na gyod sa akong mga kaliwat kay ug mawala ta sa gahom, di na ta makatabang. Lahi ra man kayo ug ordinary ra ka, di na man ka katabang nila, sa kinakuanan, igo ra ka makahatag ug pliti samtang ug duna kay gahom maka-adto ka ug Congressman, Gobernador, Mayor, ana. Makatabang gyod sa insakto nga gikinahanglan, ug wa naka sa gahom, igo ra ka sa pliti. (Those that I sow. Those people that I helped in their livelihood, in their health. I cannot abandon them most especially my relatives because if we lose in power, we cannot help. It's so much different if you are ordinary, you cannot help them, to the most, you can only provide them fare however if you have power, you can come to the Congressman, Governor, Mayor, that's it. You can exactly help them in their needs, if you are not in power; you are just up to fare.)"

\section{CONCLUSION AND RECOMMENDATION}

The life-story of Zeta is an exemplification on representation that women deserve equality at par which transcends gender in all aspects of political civilization including in the local levels of governance. Such story serves as an inspiration towards women empowerment and participation. This is embodied under the 1987 Philippine Constitution under SECTION 14 which states, "The State recognizes the role of women in nationbuilding, and shall ensure the fundamental equality before the law of women and men [12]." Such treatment of women in the Philippines clearly shows on evidence that they are well-respected with dignity, contrary to other civilizations where women were treated unequal with their counterparts.

The researcher, likewise, calls for other similar studies about women so this study can be replicated on account towards advocacy.

\section{References:}

1. (2016) Philippine Commission on Women. Women participation in politics and governance, Available: http://pcw.gov.ph/statistics/201405/womenparticipation-politics-and-governance (Accessed: October 17, 2016).

2. (2016) Philippine Commission on Women. Leadership and political participation.
Available: http://pcw.gov.ph/focusareas/leadership-political-participation (Accessed: October 17, 2016).

3. Lapiz, Gary B. (2015) Cebuano Politicians' Sustainability in Power, International Journal of Education and Research, Vol. 3 No. 5, ISSN No. 2411-5681, pp. 131-142. 


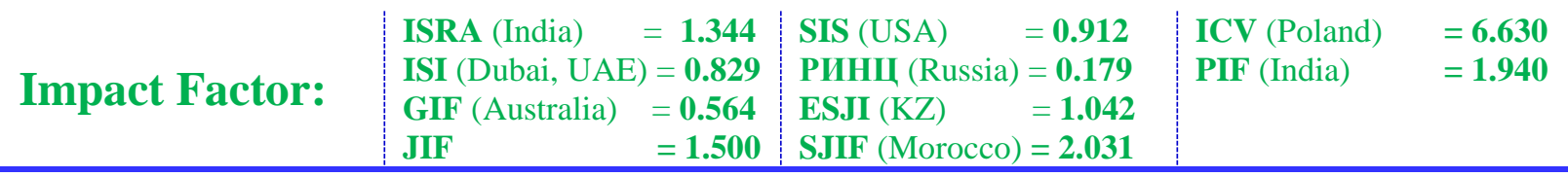

4. Ebenstein, William and Alan (2000) Great Political Thinkers. Singapore: Thomson Learning Asia.

5. Tuibeo, Amable (1998) Politics and Governance (A Critical Introduction). Makati City, Philippines: Grandwater Publications and Research Corporation.

6. Lapa, Porponio B (2004) Management Practices and Leadership Effectiveness of Barangay Chairmen in Cebu City. Unpublished Doctoral Dissertation, Cebu Normal University, Cebu Normal University.

7. Tampus, Lolito G (2000) Health Pratices, Leadership Behaviors, Personality and Performance of Managers. 2000. Unpublished Doctoral Dissertation, Cebu Normal University, Cebu City.

8. Rama, Florecita T (2002) Organizational Culture and Work Values of the Selected Local Government Units in Cebu Province: An
Organizational Development Program. 2002. Unpubished Doctoral Dissertation, Cebu Normal University, Cebu City.

9. Trani, Alan A (2007) Governance of Local Chief Executives of Talisay City, Cebu: Emerging Leadership Style. 2007. Unpublished Doctoral Dissertation, Cebu Normal University, Cebu City.

10. Lubguban, Mary Grace B (2010) Government Women Executives in Siquijor: Case Study. 2010. Unpublished Master's Thesis, Cebu Normal University, Cebu City.

11. Laplap, C.F (2010) as cited by PAGE Journal Region VII. 2010 Issue.

12. (2015) The Constitution of the Republic of the Philippines.

Available: http://www.gov.ph/constitutions/1987constitution/\#article-ii (Accessed: October 17, 2015). 